Vol. 17 (2008): 127-145.

\title{
Localisation of primary food production in Finland: production potential and environmental impacts of food consumption patterns
}

\author{
Helmi Risku-Norja \\ MTT Agrifood Research Finland, Economic Research, FI-31600 Jokioinen Finland, \\ e-mail: helmi.risku-norja@mtt.fi \\ Reija Hietala \\ Department of Applied Biology and Agroecology, FI-00014 Helsinki University, Finland \\ Hanna Virtanen \\ MTT Agrifood Research Finland, Biotechnology and Food Research, FI-31600 Jokioinen, Finland \\ Hanna Ketomäki \\ MTT Agrifood Research Finland, Economic Research, FI-31600Jokioinen, Finland \\ Juha Helenius \\ Department of Applied Biology and Agroecology, FI-00014 Helsinki University, Finland
}

The potential for and environmental consequences of localising primary production of food were investigated by considering different food consumption patterns, based on conventional and organic production. Environmental impact was assessed according to agricultural land use and numbers of production animals, both of which depend on food consumption. The results were quantified in terms of nutrient balances, greenhouse gas and acid emissions and the diversity of crop cultivation, which indicate eutrophication of watersheds, climate change and landscape changes, respectively.

The study region was able to satisfy its own needs for all farming and food consumption scenarios. Dietary choice had a marked impact on agricultural land use and on the environmental parameters considered. Organic farming for local food production resulted in higher greenhouse gas emissions. Compared with mixed diets, the vegetarian diet was associated with lower emissions and nutrient surpluses, but also with reduced crop diversity. The arable areas allocated to leys and pastures were also smaller.

The study area represents a predominantly rural region and is a net exporter of agricultural produce. Therefore, only part of the environmental impact of food production results from local needs. Both the 
Risku-Norja, H. et al. Local food, environmental impacts of food consumption

differences among the dietary options and the overall environmental benefit of localised primary food production were greatly reduced when considering total agricultural production of the region. Much of the negative impact of agriculture is due to food consumption in the densely populated urban areas, but the consequences are mainly felt in the production areas. The environmental impacts of localisation of primary food production for the rural areas are small and inconsistent. The results indicate the importance of defining 'local' on a regional basis and including the urban food sinks in impact assessment.

Key-words: food production, food consumption, conventional and organic local production, dietary changes, production potential, environmental impacts 
Vol. 17 (2008): 127-145.

\section{Introduction}

Problems related to food production are of great public concern. This is partly due to restructuring of markets for increased global production and consumption, and the cumulative economic forces that drive the food trade towards increased centralisation. Globalisation, or centralisation, is governed by prevailing economic conditions that favour scaling-up of industrial production and establishment of fewer, larger trans-national food corporations (e.g. Whatmore 2002). The standard arguments in favour of global food markets are free trade and competition. This appeals to consumers because food prices are lower due to economies of scale. The centralisation of food production on a global scale is the prevailing trend and well-established structures have been developed to secure profitability of the trade.

Industrial, global food production also has negative impacts on food safety, food security and on the environment, and its social justification has been questioned (e.g. Nabhan 2002, Whatmore 2002, Halweil 2004). In response to current developments and increasing consumer awareness, there is growing interest in alternative supplies of food. The proponents argue that geographical and social distance between food production and consumers leads to alienation of consumers. The arguments in favour of more local food production include improved food quality, greater safety and security, better environmental and animal welfare, improved rural livelihoods, strengthened regional economics and cultural heritage, and enhanced social responsibility in terms of food equity and access at national and global levels ( e.g. Kloppenburg et al. 1996, Hinrichs 2000, Mardsen 2000, Francis et al. 2003, Goodman 2003, Hinrichs 2003, Morris \& Buller 2003, Ilbery \& Maye 2005, Pretty et al. 2005, Holloway et al. 2007). Consumer-focused discussions have paid particular attention to overall chemicalisation of food and to the healthiness, cleanliness, freshness, taste and to high-quality specialist food products ( e.g. Nygard \& Storstad 1998, Tuorila 2000, Prescott et al. 2002, Murdoch $\&$ Miele 2003, Carlsson et al. 2005, Ilbery \& Maye
2005, Herro 2006, Roe 2006). Local, organic, slow and vegetarian foods, as well as fair trade food, appear as attempts to reconcile food production and food consumption, and the associated social, environmental and ethical issues, with personal choice, healthiness and tastiness.

In literature dealing with food systems the feasibility in terms of production capacity has not been the issue. In contrast to the mainstream food system research, agro-food studies approach alternative food supplies in more physical terms. Research related to environmental impacts of local, domestic and organic food production and of dietary choices, is active, but to date the results are inconclusive. In Sweden, it was shown that substituting one to several imported food items with local or domestic products over the product life cycle had a positive impact on the environment (Carlsson-Kanyama 1998a, Carlsson-Kanyama 1998b, Sundqvist et al. 2001, Carlsson-Kanyama et al. 2003, Johansson 2005). Energy consumption associated with domestic food supply on the other hand can be greater than that for imported food, depending on production methods and transport distances (Cowell \& Parkinson 2003, Roy et al. 2007). Several studies on the impact of dietary choices have shown that in comparison with crop cultivation, animal husbandry is more resource intensive, suggesting that crop production, linked with a vegetarian diet, is an environmentally preferable option (Carlsson-Kanyama 1998a, Vijver 2002, Helms \& Aiking 2003, Keyzer et al. 2003, Zhu \& Ierland 2004, RiskuNorja \& Mäenpää 2007).

Product-based life-cycle inventories, as well as assessments of farming practices, indicate environmental benefits accrue from organic farming (Cederberg \& Mattsson 2000, Pimentel et al. 2005), and organic agriculture based on animal and crop products could lead to considerable reduction in nitrogen and phosphorus leaching (Granstedt et al. 2005). Most studies suggest that the impact of organic farming on biodiversity is generally positive (Bengtsson et al. 2005, Fuller et al. 2005, Hole et al. 2005), but that the key to farmland biodiversity is habitat heterogeneity (Benton et al. 2003, Weibull et al. 2003). In Finland, environmental impacts of organic production were dealt with on a 


\section{Risku-Norja, H. et al. Local food, environmental impacts of food consumption}

national scale (Lötjönen et al. 2004, Grönroos et al. 2005, Risku-Norja \& Mäenpää 2007) and suggested benefits in terms of reduced energy consumption and nutrient loading.

Production capacity and environmental impacts of localising primary production have not been studied systematically. The present paper deals with the physical basis of food supply, and the issue of local food is approached from the viewpoint of primary production. The focus is, thus, on the hinterlands of the urban consumption areas which are crucially important regarding food security and environmental stewardship, the key elements for sustainable agro-ecosystems (Helenius et al. 2007). The aim is to assess 1) regional production capacity in relation to local food consumption including the current use and the potential to increase consumption of local wild fish, game and berries, and 2) environmental impacts of different food consumption patterns associated with local food supply. The results are used to discuss 'local' and localised food production from the standpoint of primary production. In this study both organic and conventional production are accounted for and both are confined within the study area. This was done because usually food that is labeled as organic is only a guarantee that the production fulfils the strict criteria defined for organic production, but does concern geographic origin.

The study comprises one part in an interdisciplinary food system research project dealing with the environmental and economic impacts and learning challenges of localising food systems at province level in a Finnish case (Seppänen et al. 2006, Helenius et al. 2007).

\section{Material and methods}

"Local food" is a broad term containing different dimensions ranging from physical space to historical, cultural and social features and covering also high-quality specialist food products with a guarantee for origin or traditional speciality (e.g. Morris \& Buller 2003, DuPuis \& Goodman 2005, Holloway et al. 2007). A more geographically tuned definition implies, that food production and consumption are spatially close (e.g. Kloppenburg et al. 1996, Hinrichs 2000, Holloway \& Kneafsey 2000, Tansey \& Worsley 2000, Renting et al. 2003, Watts et al. 2005). Here, the spatial approach was adopted, 'local' implying a provincial scale in Finland. The study focuses on the production capacity of the target area in terms of the basic domestic foodstuffs; meat, milk, eggs, fish, grains, potatoes, sugar, oilseeds, vegetables, fruits and berries, and on the environmental impacts of their production. These items represent about $90 \%$ of the current average food consumption in Finland. In addition to food for humans, animal feed was assumed to be produced in the same area. The special, authentic or traditional products of the region, the geographic origin of which is important in marketing, are not considered here. Such niche products are produced for specific consumer groups and for export and they were, therefore, beyond the remit of this study.

The target area of the research was the province of South Savo, in eastern Finland. The impacts on the landscape and the feasibility of increasing the share of wild products in the kitchens of the local schools were studied in the municipality of Juva (Fig.1). South Savo comprises about 3\% (161,000 inhabitants) of the total population, $5 \%$ of the total land area and $4 \%$ of the total agricultural area of Finland (Statistics Finland 2005). The South Savo region is one of the less developed rural areas in Finland, with a lower average income, higher level of unemployment and with a marked contribution of agriculture to economic life.

Only the agricultural sector of food production was addressed, and the impacts on the environment were assessed on the basis of agricultural land use and the numbers of production animals. These vary depending on dietary choices and methods of production. Agricultural land use and the numbers of farm animals in 2002 (Ministry of Agriculture and Forestry 2002, 2003b, 2003c) were taken as the controls against which changes were compared. These data were also used to estimate the current extent of food self-sufficiency in the target area.

Localisation was assumed to involve only agricultural land and not other land use type; in the 


\section{AGRICULTURAL AND FOOD SCIENCE}

Vol. 17 (2008): 127-145.

Fig.1. Index map showing the target area in Finland. The insert figure at right presenting the municipality of Juva shows the strong linear NW-SE linearity created by the advancing ice front during the glacial period and characteristic of the geomorphology of the region. The dark areas in the insert figure are field plots, which are located between the tilly forested ridges.

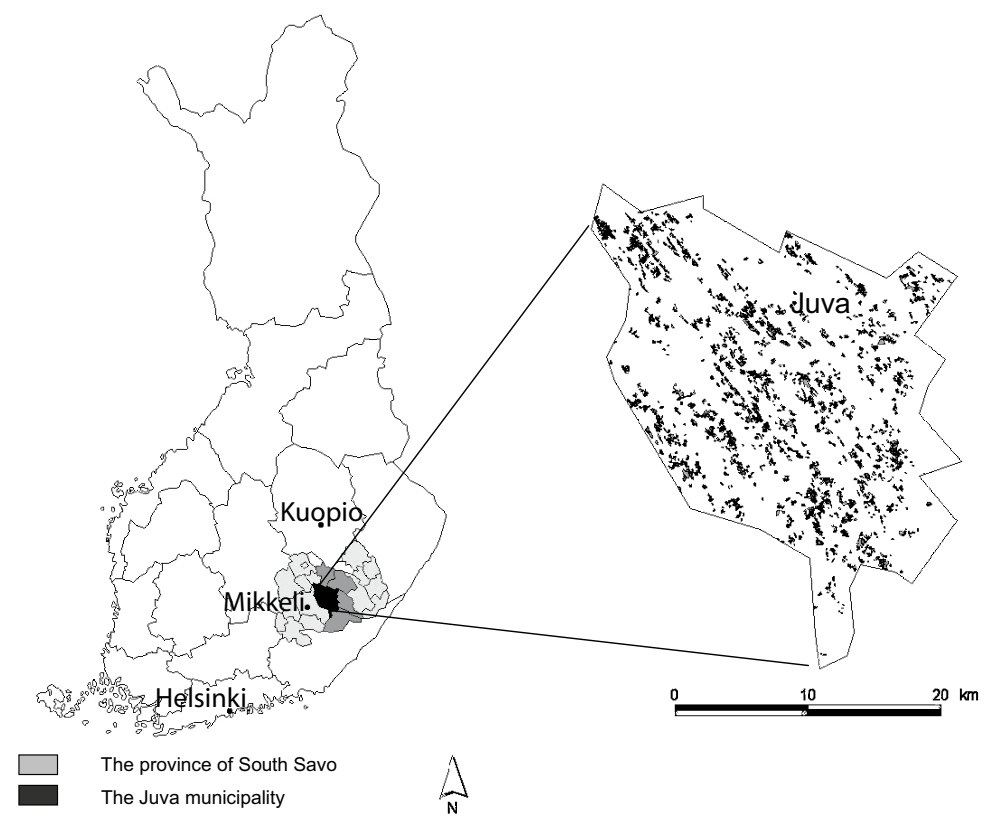

remaining of the farmland not needed to satisfy the local demand, the status quo was maintained. Similarly, the farm animal production that exceeded local consumption was redistributed according to the situation in 2002. The basic assumption was that the livestock is maintained on locally grown feed, both for organic and conventional animal husbandry; therefore the output per animal was also the same. However, compared with conventional production, the yields per hectare are up to $30 \%$ lower for organic crop production (Lötjönen et al. 2004, Risku-Norja \& Mäenpää 2007), and there were therefore differences in the areas of agricultural land needed for food and feed production.

The primary data sources were the digital spatial field parcel register, the register of domestic animals (Ministry of Agriculture and Forestry 2003b), the yearbook of farm statistics (Ministry of Agriculture and Forestry 2003c) and food consumption statistics (Ministry of Agriculture and Forestry 2003a). The per capita consumption of wild berries and catches of game and fish were based on existing statistics (Salo 2002, Game and Fishery Research Institute 2004). Long-term av- erage statistics on crop yields per hectare and on outputs of animal products per animal (Ministry of Agriculture and Forestry, annual issues) were used to calculate the required farmland allocations for each of the localised diet options.

In localised primary food production, the changes in food consumption cause concomitant changes in the demand for various agricultural products. The starting point was local food demand, which defines the farmland required and the farm animal allocation to meet local needs. Environmental impacts were estimated on the basis of changes in these key parameters.

The production potential, farmland allocation and environmental impact of farming to satisfy the local demand for food was considered for four locally produced food consumption options and for both conventional and organic farming: I- the present day average Finnish diet, II - a diet based on the national standard dietary recommendations, III - a mixed diet with no pork and poultry and IV a vegetarian diet (Table 1). The energy intake of the diets was kept constant, and they were nutritionally balanced in terms of reasonable daily intakes of 
Risku-Norja, H. et al. Local food, environmental impacts of food consumption

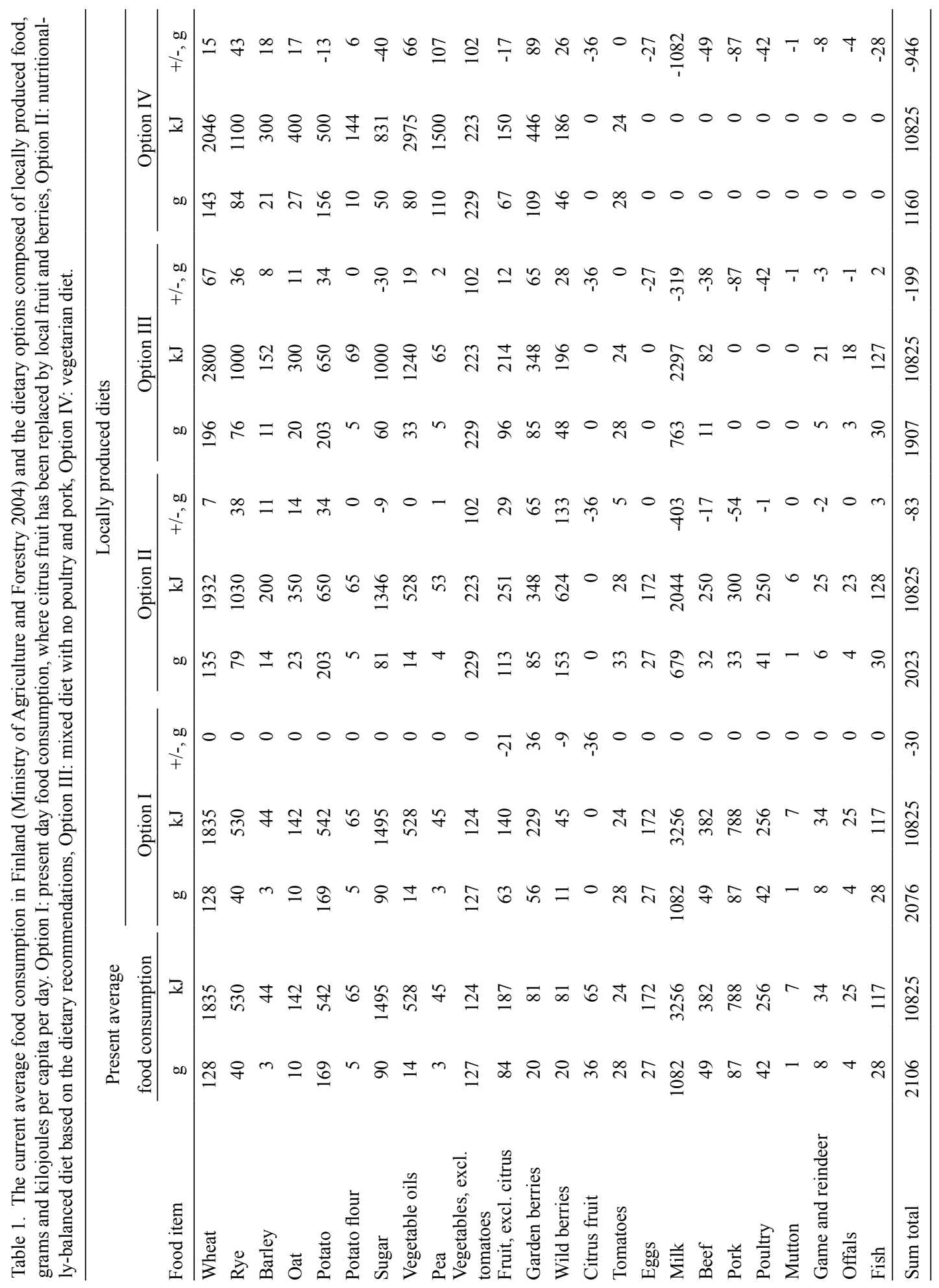


Vol. 17 (2008): 127-145.

carbohydrates, fats and proteins. For each option, both conventional and organic production systems were considered. In relation to the dietary recommendations, the current diet is still biased towards animal products, although vegetable consumption has slowly increased during the past years (Heikkinen \& Maula 1996). This bias was corrected in option two. In option three the meat was the byproduct of milk production and was assumed to be consumed locally. Option four was a pure vegetarian diet satisfied with locally cultivated food crops. In all options, the imported fruit was substituted with local fruit and wild and cultivated berries.

The environmental impact assessment included soil-surface nutrient balances (Oenema et al. 2003), greenhouse gas and acid emissions (IPCC 2005) and changes in landscape diversity expressed using Shannon's diversity index, SHDI (McGarigal \& Marks 1995), the value of which increases as the number of different land cover classes increases and/or the proportional distribution of the area among land cover classes becomes similar. The chosen parameters indicate the nutrient loading potential of the watersheds, climate change and biodiversity, respectively.

The numerical quantifications were based on the volumes of consumed plant and animal products. Consumption defines the area needed for various cultivated food plants and the numbers of different production animals. Based on the numbers and feed requirements of the production animals, the area needed for different feed crops was calculated. The nutrient balances and greenhouse gas and acid emissions were calculated from the extent and distribution of farmland, and from the animal numbers. The Shannon diversity index was derived from the land use data. Both conventional and organic production systems were accounted for.

The results on production potential were expressed relative to self-sufficiency of the various basic food products. For calculating the production potential, the following data were needed: 1) number of inhabitants, 2) food consumption per capita, 3) consumption of the various feedstuffs per animal, 4) yield per hectare of the various crops, 5) factors for converting yields to food and 6) output per animal of the various animal products.
Quantification of the environmental impacts in South Savo area required additional data: 7) phosphorus and nitrogen content of the yields and seeds, 8) fertilizer application levels for the cultivated crops, 9) nitrogen losses, 10) amount of manure per animal and its phosphorus and nitrogen contents, 11) biological nitrogen fixation, 12) emissions of methane $\left(\mathrm{CH}_{4}\right)$ from the production animals 13$)$ amount of acid fallout in the form of nitric acid $\left(\mathrm{HNO}_{3}\right)$, originating from storage and handling of dung and from nitrogen fertilisers. The greenhouse gas and acid emsissions from agriculture into the atmosphere were expressed as $\mathrm{CO}_{2}$ and $\mathrm{SO}_{2}$ equivalents, respectively.

The details of the calculations and the exact figures for the calculated parameters have been published in a technical report (Risku-Norja et al. 2007), and can be obtained on request from the authors.

For the emissions of greenhouse gases - nitrous oxide $\left(\mathrm{N}_{2} \mathrm{O}\right)$, methane $\left(\mathrm{CH}_{4}\right)$ and carbon dioxide $\left(\mathrm{CO}_{2}\right)$ from the soil, the average Finnish annual value of 2.35 tons per hectare (Statistics Finland 2007) was used, and the airborne fall-out of nitrogen was assumed to be $2.2 \mathrm{~kg}$ per hectare per year ${ }^{1}$. To compare the impact of animals of very different sizes, such as cows and poultry, the actual numbers of animals were converted into animal units, with one unit corresponding to the impact of one milking cow (Ministry of the Environment 1998).

The results for farmland requirements were based on long-term regional averages of the yield and production levels, and they are reliable also in absolute terms. The national averages of soil greenhouse emissions and nitrogen fall-out used with the regional averages for calculating the nutrient balances and gaseous emissions in reality hide large variation due to differences in soil type, climate, local geomorphology, and production conditions. The results are, therefore, somewhat less accurate. However, they show the relative differences between the dietary options and they are useful for comparative purposes in the way they have been used in this study.

Finnish Meteorological Institute, average from Punkaharju measuring station during the years 1998-2002 
Risku-Norja, H. et al. Local food, environmental impacts of food consumption

\section{Results}

\section{Current food self-sufficiency}

The agriculture of the study area is heavily focused on milk and outdoor vegetable production, and these are produced well beyond local demand. Other than that, crop cultivation is clearly deficient. Besides outdoor vegetables, only oat and barley are produced in excess. Except for beef, the by-product of dairy cattle, animal production - eggs, pork and poultry - is deficient (Fig. 2). The grain and roughage for animals is produced locally, but the protein feed (mainly soya) is imported.

The results show the degree of food self-sufficiency that could be realised within the current production structure, if the food produced were used to satisfy local demand, and only the excess were exported. In reality the situation is not that simple because food is imported into the area, even if production meets or exceeds local consumption. Similarly, food is exported although production does not cover local consumption. The results provide, however, an approximation of the status quo of supply and demand for the various foodstuffs in the re- search area. They also demonstrate that the different foodstuffs require different population basis to balance supply and demand.

\section{Feasibility of localising primary food production}

The area was calculated for agricultural land required to produce the food for local consumption according to the four dietary options. With each option, the land use for both conventional and organic production was considered (Table 2 ).

Concerning the basic foodstuffs, the region was able to satisfy its own demand, even if production was based on organic farming. Depending on the diet, conventional farming would require 35-69\% of the available agricultural land. If organically produced, the current average food consumption (option I) would require all the cultivated land area to satisfy local demand, but with the other options only part of cultivated land area (58-79\%) would be needed. Localising primary production for own food consumption would, in any case, require some redistribution of primary production.

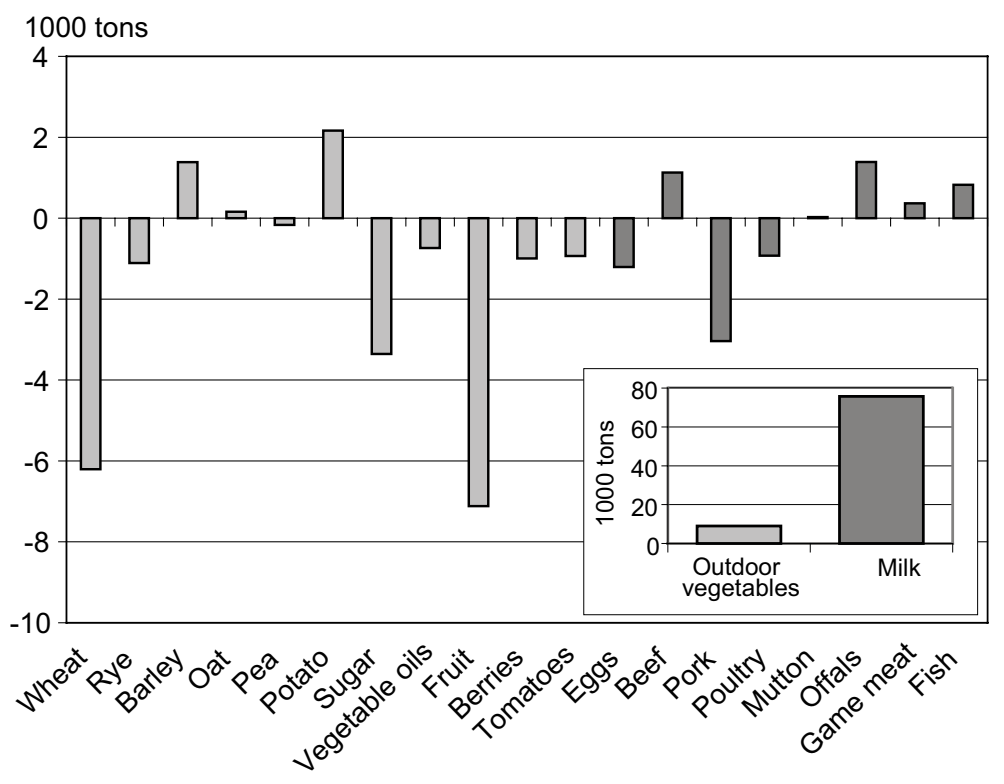

Fig. 2. Net production in excess of local consumption of the food products in 2002 in the province of South Savo, 1000 tons per year. Milk and outdoor vegetables are shown in the insert figure, because their production volumes are tenfold compared to the rest. 
Vol. 17 (2008): 127-145.

Table 2. The area needed for production of local food in the province of South Savo expressed as hectares, hectares per capita and as percentage from the present day total area of farmland in the province. Option I: present day food consumption, where citrus fruit has been replaced by local fruit and berries, Option II: nutritionally-balanced diet based on the dietary recommendations, Option III: mixed diet with no poultry and pork, Option IV: vegetarian diet.

\begin{tabular}{lcrrrr}
\hline Options & $\begin{array}{c}\text { Conventional } \\
\text { production }\end{array}$ & $\begin{array}{c}\text { ha/ } \\
\text { capita }\end{array}$ & $\begin{array}{c}\text { Organic } \\
\text { production }\end{array}$ & $\begin{array}{c}\text { ha/ } \\
\text { capita }\end{array}$ \\
\hline I & ha & 53314 & 0.33 & 79452 & 0.49 \\
& $\%$ & 69 & & 102 & \\
II $\quad$ ha & 42086 & 0.26 & 61132 & 0.37 \\
& $\%$ & 54 & & 79 & \\
III ha & 31250 & 0.19 & 44729 & 0.27 \\
& $\%$ & 40 & & 58 & \\
IV ha & 27311 & 0.17 & 50075 & 0.31 \\
& $\%$ & & & 64 & \\
total area, ha & 77673 & & & \\
\hline
\end{tabular}

\section{Role of wild food products}

Everyman's right in Finland entitles people to gather wild berries and mushrooms, as well as to rodfish and ice fish, without permission being required from the landowner. Hunting and other forms of fishing are controlled with licences. Wild products from nature have their place in the average Finnish diet, and in South Savo their share is higher than the average in Finland (Salo 2002). An insight into the role of the wild berries was obtained by considering the volume of wild berries used in the kitchens of the primary schools of the Juva municipality. Currently the pupils and school staff provide $68 \%$ of the wild berries used in schools, the rest being bought from private gatherers or wholesalers. The possibility to increase the use of local wild berries was estimated by considering two options in which the fruit used in the school kitchens was replaced partially or completely with wild berries (Table 3 ).

The potential of exploitable wild products is far greater than is actually used (Ministry of Agriculture and Forestry 2003c), so the substitution of fruit with local wild berries is plausible. School lunches are free, but the costs of the meals are accounted for in the municipal budgets. The substitution options slightly increased the costs of the school meals, but the difference were marginal (Table 3).

\section{Impact on landscape}

The impact of localising food production on the landscape was considered in the Juva municipality. Because only the changes in agricultural land use were taken into account, the changes in landscape diversity actually describe the changes in crop diversity and in other farmland use (fallow, tree plantation, area dedicated for specific agri-environmental measures etc.), which link the visual landscape with available ecological niches and species diversity.

Adjusting food production so as to satisfy local demand for food would generally decrease the area of farmland dedicated to production of cereals, grass and pastures. However, the areas for fruit and berries, and for oilseed crops and peas, would increase if the imported fruits and soya were replaced with domestic items. The considered diet options differ regarding SHDI values but, within each option, there were few differences between conventional and organic production (Fig. 3a). The mixed diets had higher SHDI values than the vegetarian diet. This is because in the vegetarian option there is no feed production; consequently permanent pastures and grasslands are absent, which has a negative impact on the diversity of wild species.

When the farmland in excess of local demand was considered, compared with the situation in 2002 (SHDI 1.96), the SHDI values increased slightly for all four local-production dietary options (Fig. 3b). This is because the proportional distribution of the area among the land cover classes evened out. Although the number of plant species was the same, in 2002 the cultivation was concentrated more on larger areas of crop species, especially of cereals. Within each diet the organically produced option resulted in slightly higher SHDI values, and the organically produced vegetarian diet had the highest value. However, compared 


\section{Risku-Norja, H. et al. Local food, environmental impacts of food consumption}

Table 3. The total consumption of fruit and wild berries ( $\mathrm{kg} / \mathrm{year})$ and its monetary value (€/year) in primary schools in the municipality of Juva (Muilu 2004). In the final row the data are presented as grams per pupil per day. Option A: Half of the fruit used in school kitchens has been substituted with wild berries out of which $1 / 3$ are lingonberries and $2 / 3$ are blueberries, Option B : All fruit used in school kitchens has been substituted with wild berries out of which 1/5 are lingonberries, $2 / 5$ are raspberries and $2 / 5$ are blueberries.

\begin{tabular}{|c|c|c|c|c|c|c|}
\hline & \multicolumn{2}{|c|}{2002} & \multicolumn{2}{|c|}{ Option A } & \multicolumn{2}{|c|}{ Option B } \\
\hline & $\mathrm{kg} /$ year & $€ /$ year & $\mathrm{kg} /$ year & $€ /$ year & $\mathrm{kg} /$ year & $€ /$ year \\
\hline \multicolumn{7}{|l|}{ Wild berries } \\
\hline Lingonberry & 450 & 225 & 1160 & 1650 & 1300 & 1400 \\
\hline Blueberry & 305 & 730 & 765 & 1300 & 860 & 1300 \\
\hline Raspberry & 0 & 0 & 0 & 0 & 220 & 1000 \\
\hline in total & 755 & 955 & 1925 & 2950 & 2380 & 3700 \\
\hline \multicolumn{7}{|l|}{ Garden berries } \\
\hline Strawberry & 220 & 680 & 220 & 680 & 220 & 680 \\
\hline Raspberry & 115 & 135 & 115 & 135 & 115 & 135 \\
\hline Redcurrant & 70 & 160 & 70 & 160 & 70 & 160 \\
\hline Blackcurrant & 110 & 200 & 110 & 200 & 110 & 200 \\
\hline in total & 515 & 1175 & 515 & 1175 & 515 & 1175 \\
\hline \multicolumn{7}{|l|}{ Fruit } \\
\hline Citrus fruit & 420 & 645 & 210 & 322.5 & 0 & 0 \\
\hline Melon & 200 & 320 & 100 & 160 & 0 & 0 \\
\hline Banana & 270 & 475 & 135 & 237.5 & 0 & 0 \\
\hline Apple & 420 & 700 & 210 & 350 & 0 & 0 \\
\hline Other & 95 & 220 & 47.5 & 110 & 0 & 0 \\
\hline in total & 1405 & 2360 & 702.5 & 1180 & 0 & 0 \\
\hline Fruit and berries in total & 2675 & 4490 & 3142.5 & 5305 & 2895 & 4875 \\
\hline \multirow[t]{2}{*}{ Fruit and berries per pupil a year } & 2.5 & 4.2 & 3.0 & 5.0 & 2.7 & 4.6 \\
\hline & $\mathrm{g} /$ day & cents/day & g/day & cents/day & g/day & cents/day \\
\hline Fruit and berries per pupil per day & 12.6 & 2.1 & 14.8 & 2.3 & 13.6 & 2.3 \\
\hline
\end{tabular}
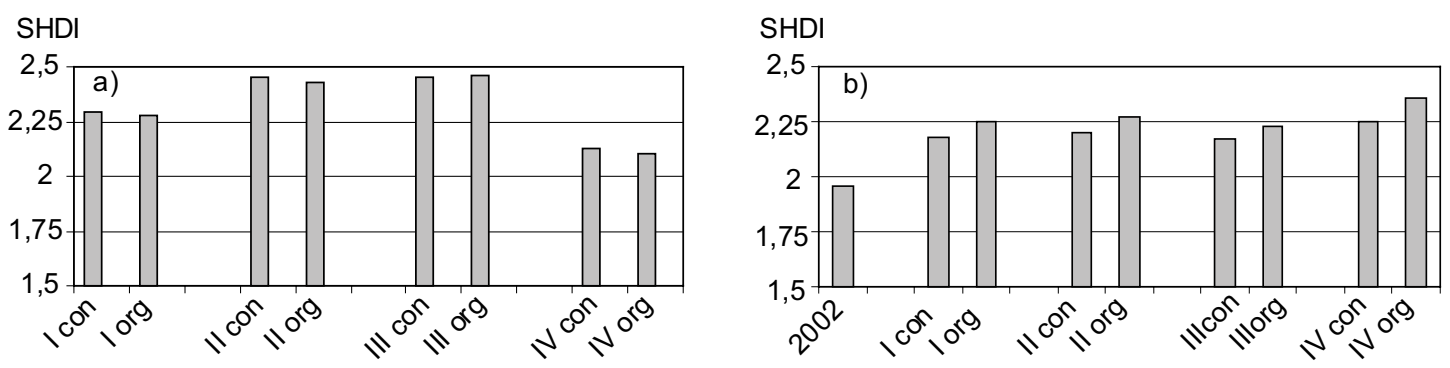

Fig. 3. Diversity of cultivated plants in the Juva municipality expressed as the Shannnon diversity index (SHDI). a) The SHDI values, when only the farmland needed for local demand is considered. b) The SHDI values for the year 2002 and for different dietary options, when also the farmland in excess of local demand is considered. Option I: present food consumption, where citrus fruit has been replaced by local fruit and berries, Option II: nutritionally balanced diet based following dietary recommendations, Option III: mixed diet with no poultry and pork, Option IV: vegetarian diet. con = conventional production, org $=$ organic production. 
Vol. 17 (2008): 127-145.

with the mixed diets situation, the area of permanent pastures and grasslands was reduced for the vegetarian options. Overall, the differences among the food consumption patterns were small.

\section{Impact on nutrient loading potential}

The soil surface nutrient balances were considered only for conventional production. This is because meaningful results for organic production, aiming at zero nutrient balance, require data based on in situ measurements.

The specific figures for the nutrient inputs and outputs show that the food consumption pattern had an impact on the nutrient balances (Table 4) and, therefore, on the nutrient loading potential. Of the considered dietary options, current food consumption (option I) produced the highest nitrogen and phosphorus surpluses. With an increasing share of vegetables in the diet, the surpluses of both nutrients decreased. The nitrogen surpluses ranged between 32 and $44 \mathrm{~kg} \mathrm{ha}^{-1}$ and phosphorus surplus- es between 9 - $10 \mathrm{~kg} \mathrm{ha}^{-1}$ (Table 4). The vegetarian option required the smallest area of farmland and appeared, therefore, to represent the least burden. If only local demand was considered, the volume of the nutrient surpluses was approximately halved by shifting to a vegetarian diet (option IV, Fig. 4a).

However, the differences among the diets were reduced when, after satisfying the local demand, the remaining farmland in the province was considered (Fig. 4b). This is because for the farmland in excess of local needs, farming continued and the farmland was allocated according to the situation in 2002. The vegetarian diet still represented the smallest burden, whereas the mixed diet with no poultry and pork produced almost as great a nitrogen surplus as in 2002. The reason for this was that with less manure available, the use of chemical fertilizers increased. In consequence, the nitrogen losses in form of emissions into the atmosphere were reduced, which resulted in a higher surplus in soil.

The phosphorus surpluses showed less variation. Compared with the situation in 2002, the phosphorus surpluses increased slightly in all op-

Table 4. Nitrogen and phosphorus inputs and outputs in soil-surface balances in the target area in 2002, and in the different diet options, $\mathrm{kg} \mathrm{ha}^{-1}$. Option I: present day food consumption, where citrus fruit has been replaced by local fruit and berries, Option II: nutritionally-balanced diet based on the dietary recommendations, Option III: mixed diet with no poultry and pork, Option IV: vegetarian diet.

\begin{tabular}{|c|c|c|c|c|c|c|c|c|c|c|}
\hline & \multicolumn{2}{|c|}{2002} & \multicolumn{2}{|c|}{$\mathrm{I}$} & \multicolumn{2}{|c|}{ II } & \multicolumn{2}{|c|}{ III } & \multicolumn{2}{|c|}{ IV } \\
\hline & $\mathrm{N}$ & $\mathrm{P}$ & $\mathrm{N}$ & $\mathrm{P}$ & $\mathrm{N}$ & $\mathrm{P}$ & $\mathrm{N}$ & $\mathrm{P}$ & $\mathrm{N}$ & $\mathrm{P}$ \\
\hline \multicolumn{11}{|l|}{ Input } \\
\hline Manure & 53.0 & 9.0 & 49.6 & 8.7 & 40.8 & 7.0 & 33.4 & 5.4 & 0.0 & 0.0 \\
\hline Fertilizers & 59.0 & 7.0 & 53.1 & 9.9 & 57.0 & 12.0 & 67.9 & 13.3 & 68.4 & 17.8 \\
\hline Apatite & 0.0 & 0.2 & & 0.2 & & 0.2 & & 0.2 & & 0.2 \\
\hline Seeds & 1.7 & 0.3 & 2.5 & 0.4 & 1.8 & 0.3 & 1.4 & 0.2 & 1.4 & 0.2 \\
\hline Deposition & 2.2 & 0.0 & 2.2 & & 2.2 & & 2.2 & & 2.2 & \\
\hline Biological $\mathrm{N}$ fixation & 1.4 & & & & & & & & & \\
\hline Total, kg per hectare & 117 & 16 & 107 & 19 & 102 & 19 & 105 & 19 & 72 & 18 \\
\hline \multicolumn{11}{|l|}{ Output } \\
\hline Crops & 59.0 & 9.0 & 58.9 & 10.1 & 54.0 & 9.4 & 54.1 & 9.3 & 40.6 & 8.0 \\
\hline $\mathrm{N}$ losses & 12.0 & & 14.6 & & 12.1 & & 7.7 & & 0.5 & \\
\hline Total, kg per hectare & 70 & 9 & 73 & 10 & 66 & 9 & 62 & 9 & 41 & 8 \\
\hline Surplus & 46 & 7 & 34 & 9 & 36 & 10 & 44 & 10 & 32 & 10 \\
\hline
\end{tabular}




\section{AGRICULTURAL AND FOOD SCIENCE}

\section{Risku-Norja, H. et al. Local food, environmental impacts of food consumption}
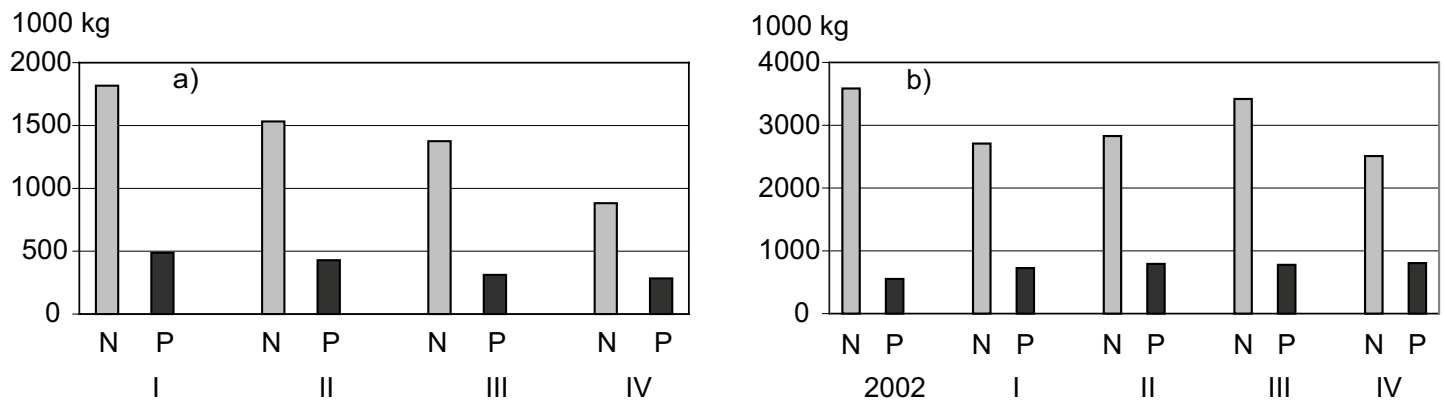

Fig. 4. Soil nitrogen (N) and phosphorus (P) surpluses, $1000 \mathrm{~kg} /$ year. a) The nutrient surpluses caused by the local needs. b) The nutrient surpluses for the year 2002 and for different dietary options in the south Savo province, when also the farmland in excess of local demand is considered. Option I: present food consumption, where citrus fruit has been replaced by local fruit and berries, Option II: nutritionally balanced diet based following dietary recommendations, Option III: mixed diet with no poultry and pork, Option IV: vegetarian diet.

tions (Fig. 4b). The increase was due to the higher input of chemical fertilizers with fixed N-P ratio compared with the year 2002.

Depending on the dietary option, the local demand caused $35-67 \%$ of the total volume of the nutrient surpluses, and the rest was due to production that was exported from the area.

\section{Impact on gaseous emissions}

The current food consumption pattern is the least favourable in terms of gaseous emissions. Greenhouse gas emissions decreased with a decreasing share of animal products in the diet. In each of the diets, the organic production option was associated with higher greenhouse gas emissions than the conventional production option (Fig. 5a). The reason is the more extensive land use in organic production with consequently, higher output of greenhouse gases from the soil.

When also agricultural production in excess of local demand was considered, the differences between the food consumption patterns were markedly reduced. Except for the vegetarian diet, associated with a lower level of total emissions, there were few differences between the dietary options
(Fig. 5b). There are two reasons for this: firstly, $70-80 \%$ of the greenhouse gas emissions in agriculture originate from the cultivated soils (Pipatti 2001). In spite of the changes in agricultural land use, the total cultivated area and, thus, also the emissions from the soil were the same regardless of the dietary option. The other reason is that for the mixed diet options I, II and III, the total number of animals expressed in animal units was the same as in 2002. The actual numbers of animals varied, and this caused some fluctuation in the amounts of gaseous emissions among options I, II and III. With the vegetarian option IV, however, the combined number of animal units was clearly lower because there were no animal products in the locally consumed food. Even for option IV, when local demand was satisfied by vegetarian products, animal husbandry did not cease in the area. However, compared with the situation in 2002, the area available for feed production was reduced. Because of the more extensive production system, the organically produced vegetarian option required more agricultural land for local consumption, leaving less farmland available for export production.

Acid emissions are due to the storage and handling of animal manure and to the nitrogen fertilisers. Therefore, the acid emissions were directly proportional to the proportion of animal prod- 
Vol. 17 (2008): 127-145.

ucts in the diet. Organic production does not include chemical fertilisers and the acid emissions were thus slightly lower (Fig. 6a). When the total acid emissions were considered, the differences between the mixed dietary options were negligible, but the vegetarian options were clearly lower in acid emissions (Fig. 6 b).

\section{Discussion}

Ultimately all food supply systems are tied to source area of food production. Here the food consumption was coupled with the physical basis of food supply by studying the production potential and environ-

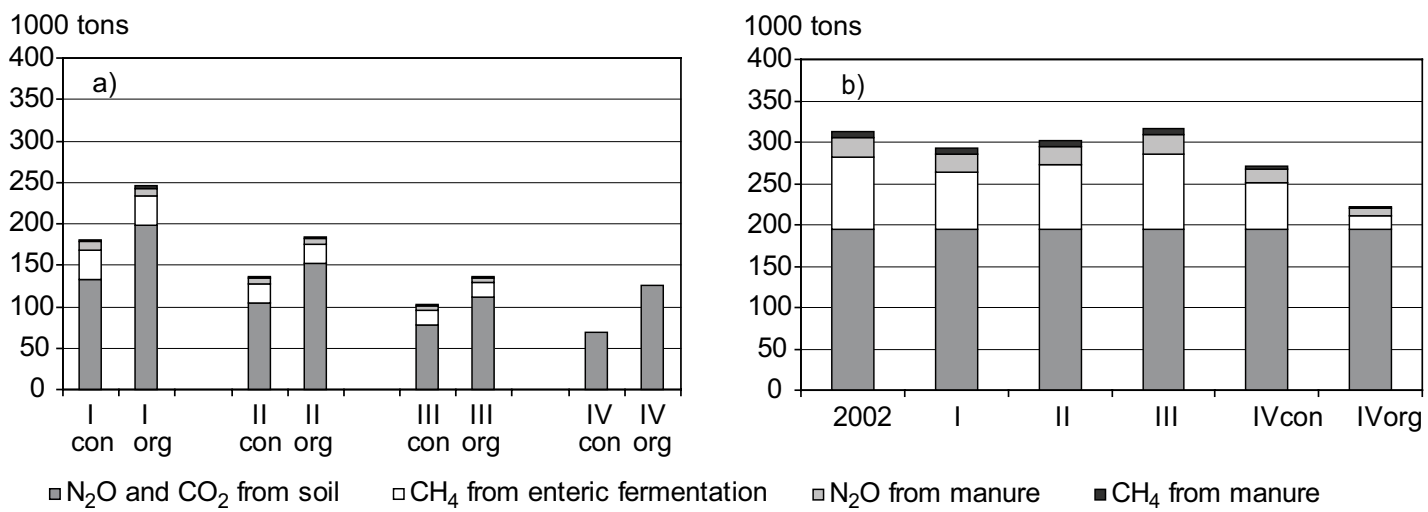

Fig. 5. The greenhouse gas emissions of agriculture, 1000 tons $\mathrm{CO}_{2}$ equivalents/year; conversion factors: 310 for $\mathrm{N}_{2} \mathrm{O}$ and for $\mathrm{CH}_{4} 21$ (Statistics Finland 2007). a) The greenhouse gas emissions caused by the local needs. b) The greenhouse gas emissions for the year 2002 and for different dietary options in the south Savo province, when also the farmland in excess of local demand is considered. Option I: present food consumption, where citrus fruit has been replaced by local fruit and berries, Option II: nutritionally balanced diet based following dietary recommendations, Option III: mixed diet with no poultry and pork, Option IV : vegetarian diet. con - conventionally produced, org - organically produced.

1000 tons

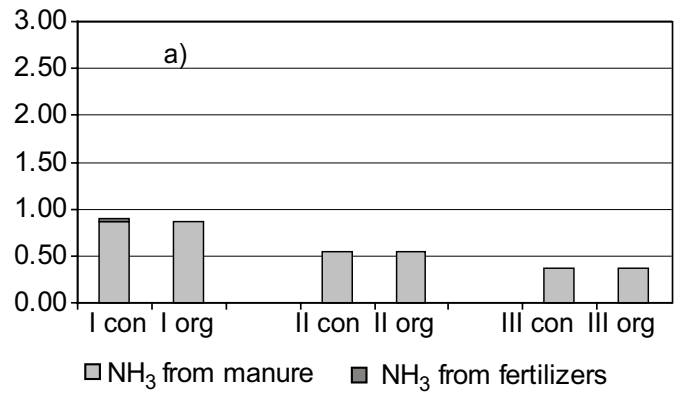

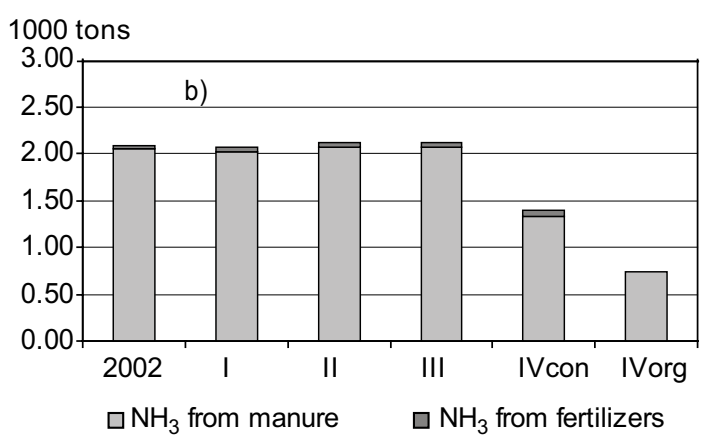

Fig. 6. The acid gas emissions of agriculture for the different dietary options, 1000 metric tons $\mathrm{SO}_{2}$ equivalents, conversion factor 1.6 (Pipatti 2002).a) The acid gas emissions caused by the local needs. b) The acid gas emissions for the year 2002 and for different dietary options in the south Savo province, when also the farmland in excess of local demand is considered. Option I: present food consumption, where citrus fruit has been replaced by local fruit and berries, Option II: nutritionally balanced diet based following dietary recommendations, Option III: mixed diet with no poultry and pork, Option IV : vegetarian diet. con = conventionally produced, org = organically produced. 


\section{Risku-Norja, H. et al. Local food, environmental impacts of food consumption}

mental impacts of localising primary production of food at the province level in Finland. To satisfy local food consumption needs, different food consumption patterns, based on conventional and organic production, were considered.

Food consumption patterns apparently do have an impact on the environment. Choosing a vegetarian diet seems to be environmentally beneficial. Compared with crop cultivation, the more resourcedemanding animal husbandry was in many respects more of a burden on the environment. A vegetarian diet has been argued for on environmental grounds (Vijver 2002, Helms \& Aiking 2003, Keyzer et al. 2003, Zhu \& Ierland 2004, Vinnari et al. 2005). On the other hand, it has been shown that livestock husbandry, more than crop cultivation, increases the value-added to agriculture. This suggests conflicting interests between environment and economy (RiskuNorja \& Mäenpää 2007). Moreover, the vegetarian diet option was not optimal in terms of its effect on the diversity of wild species. For these, the areas covered with vegetation throughout the year are especially important. In agriculture these areas include grasslands, green fallows, cultivated and natural pastures that provide abundant ecological niches for farmland birds, overwintering invertebrates and for game species, some of which have recently become rare or extinct (Tiainen \& Pakkala 2001, Hietala-Koivu 2002, Luoto et al. 2003). Dairy production is largely based on cultivated and semi-natural grasslands and grazing farm animals have contributed to the creation and maintenance of the open cultural landscape of rural areas that are rich in wild biodiversity. This shows cattle and other grazing animals in maintaining biodiversity in Finnish rural areas and shows that the environmental benefits of a vegetarian diet are not clear cut.

In response to the growing concern of environmentally conscious consumers, large-scale organic production has been offered as a possible solution to the environmental problems of agriculture (Campbell 1996, Campbell \& Coombes 1999, Morgan \& Murdoch 2000). Global organic food chains have been advocated as a solution to addressing environmental problems created by the current global food markets (Halberg et al. 2006). On the basis of land use it has been shown that global organic food supply could be feasible, and because of the high price of agrochemicals, organic production could improve the competitiveness of agriculture in developing countries (Badgley et al. 2007). However, the positive image of organic products relies heavily on the requirements for primary production, and organic production per se probably will not solve environmental or social problems in their entirety (Tansey \& Worsley 2000, Burch et al. 2001, CGFI 2002). With the increasing world population, the area of farmland per capita is continuously shrinking (United Nations 1999), while simultaneously the consumption of animal products is increasing (World Resources Institute 2006). The actual capacity of organic agriculture should be seriously considered at local and national scales before advocating large-scale shifts towards more extensive organic production.

In Finland the available farmland per capita is about 0.43 hectares. In the study area with conventional production, the farmland requirement was, depending on the diet, 0.17-0.33 hectares per capi$t a$. Food self-sufficiency, with the production of animal feed included, is thus feasible. If organically produced, current average food consumption would require 0.49 hectares per capita (without the mandatory fallow areas) in the study area. It is therefore doubtful that national food self-sufficiency in Finland could be based on organic production, unless there are considerable changes to the components of average food consumption. It is also worth noting that the calculations were based on large-scale changes in food consumption in the study area. Such changes are not realistic because the citizens have various demands and wishes that change with time, depending on general overall trends for food consumption and on prevailing personal circumstances. Although average food consumption has changed in Finland, traceable changes have taken decades (Heikkinen \& Maula 1996). The impact of the changes in consumption of locally produced food on the environment is therefore restricted and takes place over a very long time span.

At most only about half of the environmental load in the study area was due to own food consumption needs, the rest being due to the food exported from the area. The net production in excess of demand in the source area shows the potential to supply vari- 
ous foodstuffs to the consumption centres (see Fig. 2). Optimising 'local' in terms of primary production means balancing supply and demand. The geographic area, within which the balance is reached, is different for different foodstuffs. Because of the varying production structure in the hinterland source areas and of the varying population basis of the surrounding consumption centres, 'local' is spatially different in different regions.

The results show that increasing the use of local food in the countryside does not necessarily reduce the environmental load significantly. This is because the sparsely populated rural areas also produce food for urban centres. Food cannot be produced in cities to any great extent and agriculture does not, therefore, burden the city environment. Thus, although a considerable part of the negative impacts of agriculture are due to the food consumed in the densely populated urban areas, the consequences are mainly felt in the production areas. The farmers and their families suffer the unpleasant consequences of food production in their immediate surroundings, and they are often even blamed for environmental deterioration. There seems to be a need for improved dialogue and interaction between urban food consumption areas and their rural food production areas. This relationship has been largely ignored in local food projects and has resulted in apparently different interests (DuPuis \& Goodman 2005).

Inevitably the production of food that is exported causes environmental load in the source area simply due to the regional imbalance between production inputs and outputs. Relying on foreign imports does not solve the problems but only transfers them to other production areas elsewhere in the world. It is reasonable to assume that the closer the food production is to the consumers, the better the environmental aspects are taken care of (Macnaghten \& Urry 1998). It would be also easier to justify sharing the costs of the measures aimed at environmental improvement within the society. Thus, although localising primary food production does not remove environmental impacts, it is likely to enable better control of them. Instead of focusing on the arguable environmental benefits of localised or organic food production, more attention could be paid to alleviating the negative impacts.

\section{Conclusions}

The area of the case study represents a predominantly rural region and is a net exporter of agricultural products. Therefore, it was not surprising, that except for organic production, only part of the farmland would be needed to satisfy the local demand for food.

Considering food production for local needs only, the current average food consumption (option I) is environmentally the most unfavourable. An increasing share of vegetarian products in the diet decreases nutrient surpluses, and greenhouse gas and acid emissions. On the other hand, the SHDI values for the mixed diets were higher than those for the vegetarian diet. In each diet the organic production option resulted in higher greenhouse gas emissions and slightly lower acid emissions. The results from the crop diversity assessment showed that there were differences among the dietary options but, within each option, there were hardly any differences between conventional and organic production. The more similar the areas of the cultivated crops, the higher was the SHDI value representing the quantified visual diversity of the farmland.

It was assumed that for the farmland in excess of local needs the status quo was maintained. This has a strong equalising effect and, compared with the situation in 2002, the differences in the considered environmental indicators among the various locally produced diet options were smoothed out. The vegetarian diet (option IV) was associated with the lowest nutrient surpluses and gas emissions. In this case, the organic production option (IV org) appeared the most favourable. This is because with a constant total area, the greenhouse gas emissions from soil were also constant, and the variation in nutrient surpluses and gaseous emissions were due to the variable numbers of animals. The organic production option IV left less area available for feed production and therefore, a smaller number of animals could be supported. Although it was associated with the highest crop diversity, the reduced area of permanent pastures and grasslands was negative regarding the diversity of wild species. The mixed diet, with no poultry or pork (III), 


\section{Risku-Norja, H. et al. Local food, environmental impacts of food consumption}

had a large proportion of ruminants and the greenhouse gas emissions were therefore even higher than in 2002. The nitrogen surplus in soil was also fairly high, because with less manure available for fertiliser the nitrogen output in the form of emissions to the atmosphere were reduced, raising the nitrogen input/output ratio in soil.

Considering all farmland, the environmental impacts of localisation of primary food production seemed rather small and they were not consistently positive or negative. Localised production does not remove environmental impacts, and imported food is not a solution because it only transfers the impacts to the source areas.

The questions regarding localised primary food production need to be tackled so as to include both the production areas and the urban food sinks when assessing environmental impacts. "Local" is not fixed in regard of geographic distance, but varies among the different foodstuffs and among the different food production source areas.

In interpreting the results, the basic assumptions of the study should be kept in mind. Most importantly, only the agricultural food production sector was addressed and localisation was assumed to involve only agricultural land. For farmland in excess of local needs, the status quo was maintained. Both for organic and conventional animal husbandry, livestock was fed with locally-grown feed and therefore the differences in environmental performance of organically and conventionally produced local food were due to agricultural land use. In addition, only few environmental indicators were considered. The positive impacts of organic production on biodiversity, due to, inter alia, prohibition of biocide use, were not quantified. Keeping the basic assumptions in mind, this approach is easily transferred to other situations by adjusting the calculation parameters accordingly.

Acknowledgements. Many thanks to the other researchers of project group, Laura Seppänen, Minna Mikkola from the University of Helsinki, Marko Sinkkonen and Esa Aro-Heinilä from the MTT Agrifood Research Finland. The lively discussions within the interdisciplinary project group widened our perception and greatly contributed to our conclusions. We would also like to thank Professor Sirpa Kurppa and Dr. Jyrki Aakkula, MTT Agrifood Research
Finland and Dr. Roy Siddal, University of Helsinki, who critically commented on the manuscript. The research was funded by the Finnish Ministry of Agriculture and Forestry and MTT Agrifood Research Finland.

\section{References}

Badgley, C., Moghtader, J., Quintero, E., Zakem, E., Chappell, M.J., Aviles-Vazquez, K., Samulon, A. \& Perfect, I. 2007. Organic agriculture and the global food supply. Renewable Agriculture and Food Systems 22, 2: 86-108.

Bengtsson, J., Ahnström, J. \& Weibull, A. 2005. The effects of organic agriculture on biodiversity and abundance: a meta-analysis. Journal of Applied Ecology, 421: 261-269.

Benton, T.G., Vickery, J.A. \& Wilson, J.D. 2003. Farmland biodiversity: is habitat heterogeneity the key. Trends in Ecology and Evolution, 18: 182-188.

Burch, D., Lyons, K. \& Lawrence, G. 2001. What do we mean by 'Green'? In: Lockie, S. \& Pritchard, B. (eds.) Consuming Foods, Sustaining Environments. Brisbane: Australian Academic Press. p. 33-46.

Campbell, H. 1996. Organic agriculture in New Zealand: corporate greening, transnational corporations and sustainable agriculture. In: Burch, D. et al. (eds.) Globalization and Agrifood Restructuring: Perspectives from the Ausralasia Region. Avebury: Aldershot. p. 153-169.

Campbell, H. \& Coombes, B. 1999. New Zealand's organic exports: current interpretations and new directions in research. In: Goss, J. \& Lawrence, G. (eds.) Restructuring Global and Regional Agricultures: Transformations in Australasian Agrofood Economies and Spaces. Ashgate: Aldershot. p. 61-74.

Carlsson, F., Frykblom, P. \& Lagerkvist, C.J. 2005. Consumer preferences for food product quality attributes from Swedish agriculture. Ambio 34, 4-5: 366-370.

Carlsson-Kanyama, A. 1998a. Climate change and dietary choices - how can emissions of greenhouse gases from food consumption be reduced? Food Policy 23, 3/4: 277-293.

Carlsson-Kanyama, A. 1998b. Food consumption patterns and their influence on climate change: greenhouse gas emissions in the life cycle of tomatoes and carrots consumed in Sweden. Ambio 27, 7: 528-534.

Carlsson-Kanyama, A., Ekström, M.P. \& Shanahan, H. 2003. Food and life cycle energy inputs: consequences of diet and ways to increase efficiency. Ecological Economics 44, 2-3: 293-307.

Cederberg, C. \& Mattsson, B. 2000. Life cycle assessment of milk production - a comparison of conventional and organic farming. Journal of Cleaner Production, 8: 49-60.

CGFI 2002. British Crop Group Speaker Claims Organic Farming on a Global Basis Would be an Environmental Catastrophe. Available on the Internet: http://www. cgfi.org/materials/articles/2002/nov_15pr_02.htm. Cited: 19.10.2007.

Cowell, S.J. \& Parkinson, S. 2003. Localisation of UK food 
Vol. 17 (2008): 127-145.

production: an analysis using land area and energy as indicators. Agriculture, Ecosystems and Environment 94, 2: 221-236.

DuPuis, E.M. \& Goodman, D. 2005. Should we go "home" to eat?: toward a reflexive politics of localism. Journal of Rural Studies, 21: 359.

Francis, C., Lieblein, G., Gliessman, S., Breland, T.A., Creamer, N., Harwood, R., Salomonsson, L., Helenius, J., Rickerl, D., Salvador, R., Wiedenhoeft, M., Simmons, S., Allen, P., Altieri, M., Flora, C. \& Poincelot, R. 2003. Agroecology: the ecology of food systems. Journal of Sustainable Agriculture, 22: 99-118.

Fuller, R.J., Norton, L.R., Feber, R.E., Johnson, P.J., Chamberlain, D.E., Joys, A.C., Mathews, F., Stuart, R.C., Townsend, M.C., Manley, W.J., Wolfe, M.S., Macdonald, D.W. \& Firbank, L.G. 2005. Benefits of organic farming to biodiversity vary among taxa. Biology Letters, 1: 431-434.

Game and Fishery Research Institute 2004. Finnish Fisheries Statistics 2004. Available on the Internet: http:// www.rktl.fi/www/uploads/pdf/taskutilasto2004.pdf. Cited: 20.8.2007.

Goodman, D. 2003. The quality turn and alternative food practices: reflections and agenda. Journal of Rural Studies 19, 1: 1-7.

Granstedt, A., Thomsson, O. \& Schneider, T. 2005. Environmental impacts of eco-local food systems - final report from BERAS Work Package 2. SLU - Swedish University of Agricultural Sciences.

Grönroos, J., Seppälä, J., Voutilainen, P., Seuri, P. \& Koikkalainen, K. 2005. Energy use in conventional and organic milk and rye bread production in Finland. Agriculture, Ecosystems and Environment 117: 109-118.

Guthman, J. 1998. Regulating meaning, appropriating nature: the codification of California organic agriculture. Antipode 30, 2: 135-154.

Halberg, N., Alrøe, H.F. \& Kristensen, E.S. 2006. Synthesis: prospects for organic agriculture in a global context. In: Halberg, N. et al. (eds.) Global Development of Organic Agriculture: Challenges and Prospects. CABI Publishing. p. 343-367.

Halweil, B. 2004. Eat Here. Reclaiming Homegrown Pleasures in a Global Supermarket. W.W. Norton \& Company Inc. New York: World Watch Institute. 236 p.

Heikkinen, S. \& Maula, J. 1996. Finnish food consumption 1860-1993. National Consumer Research Centre. Helsinki: 1-47 p.

Helenius, J., Aro-Heinilä, E., Hietala, R., Mikkola, M., RiskuNorja, H., Seppänen, L., Sinkkonen, M. \& Vihma, A. 2007. Systems frame for multidisciplinary study on sustainability of localizing food. Progress in Industrial Ecology,4-5:328-347.

Helms, M. \& Aiking, H. 2003. Food and the environment: towards sustainability indicators for protein production. In: Tiezzi, E. et al. (eds.) Ecosystems and sustainable development. Volume 2 Advances in Ecological Sciences ed. Ashurst, UK: WIT Press. p. 1047-1056.

Herro, A. 2006. Eating Local Food May Combat E. Coli, Other Food-Borne Illnesses. 2006, Worldwatch Institute. Available on the Internet: http://www.worldwatch. org/node/4540. Cited: 20.12.7007.

Hietala-Koivu, R. 2002. Landscape and modernizing agriculture: a case study of three areas in Finland in
1954-1998. Agriculture, Ecosystems \& Environment 91, 1-3: 273-281.

Hinrichs, C.C. 2000. Embeddedness and local food systems: notes on two types of direct agricultural market. Journal of Rural Studies, 16: 295-303.

Hinrichs, C.C. 2003. The practice and politics of food system localization. Journal of Rural Studies 19, 1: 33-45.

Hole, D.G., Perkins, A.J., Wilson, J.D., Alexander, I.H., Grice, P.V. \& Evans, A.D. 2005. Does organic farming benefit biodiversity? Biological Conservation, 122: 113-130.

Holloway, L. \& Kneafsey, M. 2000. Reading the space of the farmers' market: a preliminary investigation from the UK. Sociologia Ruralis 40, 3: 285-299.

Holloway, L., Kneafsey, M., Venn, L., Cox, R., Dowler, E. \& Tuomainen, H. 2007. Possible Food Economies: A Methodological Framework for Exploring Food Production-Consumption Relaitionships. Sociologia Ruralis 47, 1: 1-17.

Ilbery, B. \& Maye, D. 2005. Alternative (shorter) food supply chains and specialist livestock products on the Scottish-English borders. Environment and Planning A, 37: 823-844.

IPCC 2005. CORRIGENDUM (GPGAUM-Corr.2001.01, 15 June 2001). Available on the Internet: http://www.ipcc-nggip.iges.or.jp/public/gp/english/. Cited: 19.10.2007.

Johansson, S. 2005. The Swedish Foodprint. An agroecological study of food consumption. SLU - The Swedish University of Agricultural Sciences. 1-96 p.

Keyzer, M.A., Merbis, M.D., Pavel, I.F.P.W. \& Wesenbeeck, C.F.A.v. 2003. Can we feed the animals? Origins and implications of rising meat demand. SWOW Working $\mathrm{Pa}$ per, 01-05R: 1-30.

Kloppenburg, J., Jr., Hendrickson, J. \& Stevenson, G.W. 1996. Coming into the foodshed. Agriculture and $\mathrm{Hu}$ man Values, 13: 33-42.

Lötjönen, T., Muuttomaa, E., Koikkalainen, K., Seuri, P. \& Klemola, E. 2004. Production technology of large-scale organic farming as an economic and ecological challenge. MTT Agrifood Research Reports 44. 131 p. In Finnish with abstract in English.

Luoto, M., Pykälä, J. \& Kuussaari, M. 2003. Decline of landscape-scale habitat and species diversity after the end of cattle grazing. Journal for Nature Conservation 11, 3: 171-178.

Macnaghten, P. \& J Urry, J. 1998. Contested Natures. London: Sage Publications Ltd. $298 \mathrm{p}$.

Mardsen, T. 2000. Food matters and the matter of food: Towards new food governance? Sociologica Ruralis 40, 1: 20-29.

McGarigal, K. \& Marks, B.J. 1995. FRAGSTATS: spatial pattern analysis program for quantifying landscape structure. PNV 351. U.S. Forest Service.

Ministry of Agriculture and Forestry, annual issues. Yearbook of farm statistics. Helsinki: Information Centre of the Finnish Ministry of Agriculture and Forestry.

Ministry of Agriculture and Forestry 2002. Agricultural census 2000. Information Centre of the Finnish Ministry of Agriculture and Forestry. Helsinki: 57-61 p.

Ministry of Agriculture and Forestry 2003a. Peruslohkojen sijainti lohkojen ala-, kehämitta- sekä viljelykasvitietoineen vuodelta 2002 Juvan kunnan alueelta. Helsinki: Information Centre of the Finnish Ministry of Agriculture 


\section{AGRICULTURAL AND FOOD SCIENCE}

\section{Risku-Norja, H. et al. Local food, environmental impacts of food consumption}

and Forestry (TIKE).

Ministry of Agriculture and Forestry 2003b. Yearbook of farm statistics 2002. Helsinki: Information Centre of the Finnish Ministry of Agriculture and Forestry.

Ministry of Agriculture and Forestry 2004. Balance sheets for food accommodities 2003. Helsinki: Information Centre of the Ministry of Agriculture and Forestry.

Ministry of the Environment 1998. Ohje kotieläintalouden ympäristönsuojelusta. (in Finnish). Available on the Internet:http://www.ymparisto.fi/download. asp?contentid=22354\&lan=fi. Cited 23.2. 2004.

Morgan, K. \& Murdoch, J. 2000. Organic vs. Conventional Agriculture: Knowledge, Power and Innovation in the Food Chain. Geoforum 31, 2: 159-173.

Morris, C. \& Buller, H. 2003. The local food sector. A preliminary assessment of its form and impact in Gloucestershire. British Food Journal 105, 8: 559-566.

Murdoch, J. \& Miele, M. 2003. Culinary networks and cultural connections: a conventions perspective. In: Hughes, A. \& Reimer, S. (eds.) Geographies of Commodity Chains. London: Pearson Education.

Nabhan, G. 2002. Coming Home to Eat: The Pleasures and Politcs of Local Foods. New York: W.W. Norton Company Ltd. $230 \mathrm{p}$.

Nygard, B. \& Storstad, O. 1998. Deglobalisation of food markets? Consumer perceptions of safe food: the case of Norway. Sociologia Ruralis 38, 1: 35-53.

Oenema, O., Kros, H. \& De Vries, W. 2003. Approaches and uncertainties in nutrient budgets: implications for nutrient management and environmental policies. European Journal of Agronomy 20: 3-16.

Pimentel, D., Hepperly, P., Hanson, J., Douds, D. \& Seidel, R. 2005. Environmental, energetc comparisons economic comparisons of conventional and organic farming systems. BioScience 55, 7: 573-582.

Pipatti, R. 2001. Greenhouse gas emissions and removals in Finland. VTT Research Notes 2094. Technical Research Centre of Finland. Espoo, Finland: 1-59 p.

Prescott, J., Young, O., O'Neill, L., Yau, N.J.N. \& Stevens, R. 2002. Motives for food choice: a comparison of consumers from Japan, Taiwan, Malaysia and New Zealand. Food Quality and Preference 13, 7-8: 489-495.

Pretty, J.N., Ball, A.S., Lang, T. \& Morison, J.I.L. 2005. Farm costs and food miles: An assessment of the full cost of the UK weekly food basket. Food Policy 30, 1: 1-19.

Renting, H., Marsden, T. \& Banks, J. 2003. Understanding alternative food networks: exploring the role of short supply chains in rural development. Environment and Planning A, 35: 393-411.

Risku-Norja, H., Hietala, R., Ketomäki, H. \& Virtanen, H. 2007. Localisation of food production and dietary changes: environmental impacts. Technical report. Agrifood Research Working Papers 135. 43 p. Available on the Internet: http://www.mtt.fi/mtts/pdf/mtts135.pdf. In Finnish with abstract in English.

Risku-Norja, H. \& Mäenpää, I. 2007. MFA model to assess economic and environmental consequences of food production and consumption. Ecological Economics 60, 4: 700-711.

Roe, E. 2006. Things becoming food and the embodied, material practices of an organic food consumer. Sociologia Ruralis 46, 2: 104-121.

Roy, P., Nei, D., Okadome, H., Nakamura, N. \& Shiina, T.
2007. Life cycle analysis of fresh tomato distribution systems in Japan considering the quality aspect. Journal of Food Engineering 86, 2: 225-233

Salo, K. 2002. Keräilytuotteet. Keräilytuotteet. Tapion taskukirja. Tapio. Statistics sheet.

Seppänen, L., Aro-Heinilä, E., Helenius, J., Hietala-Koivu, R., Ketomäki, H., Mikkola, M., Risku-Norja, H., Sinkkonen, M. \& Virtanen, H. 2006. Local food system: environmental and economic impacts and learning challenges. University of Helsinki, Ruralia institute. Seinäjoki: 1-117 p. In Finnish with abstract in English.

Statistics Finland 2007. Greenhouse gas emissions in Finland 1990-2005. National inventory report for the UNFCCC. Available on the Internet: www.stat.fi/greenhousegases.

Statistics Finland 2005. South Savo in statistics. In Finnish. Available on the Internet: http://www.esavo.fi/index.htm.

Sundqvist, Å., Jansson, A. \& Larsson, P. 2001. Strengths and limitations of localizing food production as a sustainability-building strategy - an analysis of bread production on the island of Gotland, Sweden. Ecological Economics 37, 2: 217-227.

Tansey, G. \& Worsley, T. 2000. The food system. A guide. London: Earthscan Publications Ltd.

Tiainen, J. \& Pakkala, T. (eds.) 2001. Birds. Biodiveristy of Agricultural Landscapes in Finland. Helsinki: BirdLife Finland. 33-50 p.

Tuorila, H. 2000. Pressure to change and resistance against it: consumer perceptions and acceptance of nutritionally modified foods. Agricultural and Food Science in Finland 9, 2: 165-176.

United Nations 1999. World population prospects: The 1998 revision, vol. 1, comprehensive tables. New York: UN Dept. Economic and Social Affairs, Population Division.

Vijver, M. 2002. Protein politics: Shaping the notion of eating less animal, and more plant protein foods. European Association for the Study of Science and Technology : 1-16.

Vinnari, M., Vehmas, J. \& Luukkanen, J. 2005. Animal based food consumption in the EU - do we decrease our meat consumption when the income levels rise? In: Vilska, T. \& Haanpää, L. (eds.) Life styles and social change. Essays in Economic Sociology. Turku: Turku School of Economics and Business Administration.

Watts, M., llbery, D. \& Maye, D. 2005. Making reconnections in agro-food geography: alternative systems of food provision. Progress in Human Geography 20, 1: 22-40.

Weibull, A., Östman, Ö. \& Granqvist, Å. 2003. Species richness in agroecosystems: the effect of landscape, habitat and farm management. Biodiversity and Conservation 12: 1335-1355.

Whatmore, S. 2002. From farming to agribusiness. The global agro-food system. In: Johnston, R.J. et al. (eds.) Geographics of Global Change. Malden, MA: Blackwell Publishers. p. 58-67.

World Resources Insitute 2006. Earth trends. Available on the Internet: http://www.earthtrends.wri.org/searchable db. Cited: 20.10 .2007

Zhu, X. \& lerland, E.v. 2004. Protein foods and environmental pressures: a comparison of pork and Novel Protein Foods. Environmental Sciences, 1: 254-276. 


\title{
AGRICULTURAL AND FOOD SCIENCE
}

Vol. 17 (2008): 127-145.

\section{SELOSTUS}

\section{Lähiruoka - toteutettavuus ja ympäristövaikutukset}

\author{
Helmi Risku-Norja, Reija Hietala, Hanna Virtanen, Hanna Ketomäki ja Juha Helenius \\ MTT ja Helsingin yliopisto
}

Tässä tutkimuksessa tarkastellaan tavanomaisesti ja luonnonmukaisesti tuotetun lähiruoan alkutuotantoa erilaisten ruoankulutusvaihtoehtojen pohjalta. Yhtäältä tarkastellaan lähiruoan toteutettavuutta kohdealueella, toisaalta miten lähiruokajärjestelmä toteutuessaan heijastuisi ympäristöön. Paikallinen ruoantuotanto tässä yhteydessä tarkoittaa, että a) tuotanto ja kulutus ovat alueellisesti lähellä toisiaan ja että b) myös kotieläintalouden rehut tuotetaan samalla alueella. Tarkastelu on rajattu kotimaisiin peruselintarvikkeisiin.

Ympäristövaikutusten arviointi perustuu maankäyttöön ja kotieläinmääriin, jotka määräytyvät ruoankulutuksen mukaan. Arvioinnissa käytettiin ravinnetaseita, kasvihuonekaasu- ja happamoittavia päästöjä sekä viljelykasvimonimuotoisuutta kuvaamaan vesistöjen rehevöitymistä, ilmastonmuutosta sekä maiseman ja luonnon monimuotoisuuden muutoksia.

Ruokavaliovaihtoehdosta ja tuotantotavasta riippumatta tutkimusalueen maatalousmaa riittää tuottamaan ruoan alueen omalle väestölle. Luonnonmukaisesti tuotettu paikallinen ruoka aiheuttaa enemmän kasvihuonekaasupäästöjä kuin tavanomaisesti tuotettu. Kasvis(painotteiset) ruokavaliovaihtoehdot tuottavat vähemmän sekä kaasumaisia päästöjä että ravinneylijäämiä, mutta toisaalta monivuotisten nurmien ja laidunten pinta-ala supistuu, mikä on epäedullista luonnon monimuotoisuuden kannalta.
Tutkimusalue on pääosin maaseutua, ja maataloustuotanto suuntautuu sen vuoksi alueen ulkopuolelle. Vain osa tuotannon ympäristövaikutuksista johtuu alueen oman väestön tarpeista. Kun otettiin huomioon alueen koko maataloustuotanto, olivat maankäytön ja ravinnekuormituksen erot eri ruokavaliovaihtoehtojen välillä hyvin pieniä eikä suuria eroja ollut kasvihuonekaasu- tai happamoittavissa päästöissäkään. Luomutuotetussa kasvisruokavaliossa kaasumaisia päästöjä tulee jonkin verran vähemmän kuin muissa vaihtoehdoissa, mutta samalla monivuotisten laidunten ja nurmien pinta-ala vähenee.

Maaseutualueilla lähiruoan tuotannon ympäristövaikutukset vaihtelevat tuotantotavasta ja ruokavaliosta riippuen, mutta mikään vaihtoehto ei ole yksiselitteisesti muita parempi. Maatalous ei kuormita ympäristöä asutuskeskuksissa, mutta niissä kulutettu ruoka kuormittaa ympäristöä siellä, missä se tuotetaan. Lähiruoka tuleekin määritellä siten, että sen piiriin kuuluvat sekä ruoantuotantoalueet maaseudulla että ruoankulutus kaupungeissa. Lähiruoka ei välttämättä vähennä ympäristökuormitusta, mutta mitä lähempänä ruoantuotannon ympäristökuormitus tuntuu, sitä paremmin ympäristönäkökulma tulee otetuksi huomioon ja sen helpompaa on perustella ympäristönhoidon kustannusten jakamista yhteiskunnassa. 